\title{
PANDANGAN DUNIA HUMANISME TEOSENTRIS DALAM NOVEL KANTRING GENJER-GENJER KARYA TEGUH WINARSHO
}

\author{
Badarudin Safe'i ${ }^{1}$ dan Siti Mustaghfiroh ${ }^{2}$
}

STIES Darul Huda Mesuji Lampung ${ }^{1}$, IAIN Metro Lampung ${ }^{2}$

email: albadar877@gmail.com ${ }^{1}$, vieroh48@gmail.com²

\begin{abstract}
ABSTRAK
Penelitian ini mengambil objek material novel Kantring Genjer-Genjer karya Teguh Winarsho. Penelitian ini bertujuan untuk mengetahui pandangan dunia (vision du monde) pengarang yang diekspresikan dalam novel Kantring Genjer-Genjer. Sementara itu, teori sastra yang digunakan dalam penelitian ini adalah teori Strukturalisme Genetik. Teori sastra ini dikembangkan oleh Lucien Goldmann. Menurut teori ini, antara struktur karya sastra dengan struktur sosial dianggap memiliki hubungan, tetapi hubungan tersebut bukan bersifat langsung melainkan dimediasi oleh pandangan dunia. Dengan kata lain, pandangan dunia menjadi jembatan penghubung antara struktur karya sastra dan struktur sosial pengarang. Metode yang digunakan adalah metode dialektik. Metode ini bekerja dengan pemahaman bolak-balik antara pandangan dunia, struktur teks, dan struktur sosial pengarang.
\end{abstract}

Kata Kunci: kantring genjer-genjer, strukturalisme genetik, humanisme teorsentris

\section{ABSTRACT}

This study takes the material object of the Kantring Genjer-Genjer by Teguh Winarsho. This study aims to determine the world view (vision du monde) of the author expressed in the Kantring Genjer-Genjer. Meanwhile, the literary theory used in this study is the theory of Genetic Structuralism. This literary theory was developed by Lucien Goldmann. According to this theory, the structure of literary works with social structures is considered to have a relationship, but the relationship is not directly but mediated by worldview. In other words, the worldview becomes the link between the structure of literary works and the social structure of the author. The method used is the dialectical method. This method works by understanding back and forth between worldview, text structure, and the social structure of the author.

Keyword: kantring genjer-genjer, genetic structuralism, theocratic humanism 


\section{PENDAHULUAN}

Sastrawan sebagai pencipta karya sastra juga merupakan anggota dari suatu masyarakat. Ia hidup dan berinteraksi dengan orang lain yang ada di sekitarnya. Hal ini menjadikan adanya hubungan yang kuat antara sastrawan dengan masyarakatnya (Sumardjo, 1982:15). Melalui karya sastra yang diciptakan, seorang sastrawan ingin menampilkan gambaran yang jelas tentang kehidupan. Kehidupan sebagai kenyataan sosial mencakup hubungan antarmasyarakat, antara masyarakat dengan orang perorang, antarmanusia, antarperistiwa yang terjadi dalam batin seseorang. Peristiwa-peristiwa yang pernah terjadi dalam batin seseorang-yang seringkali dijadikan bahan sastra - adalah pantulan hubungan seseorang dengan orang lain atau masyarakat (Damono, 1978:1).

Persoalan sosial yang ada dalam masyarakat seringkali tercermin dalam karya seni yang tercipta termasuk di dalamnya seni sastra. Apabila pengarang memiliki kepekaan yang tinggi, pastilah karya sastranya akan mencerminkan kritik sosial yang ada dalam masyarakat tersebut, meskipun dimunculkan secara tersirat (Damono, 1983:22). Pendapat Damono tersebut sejalan dengan kenyataan bahwa munculnya sastrawan ke permukaan juga tidak terlepas dari karya sastra yang diciptakannya. Seberapa jauh karya-karyanya memiliki keunggulan di antara karya-karya sastrawan yang lain dan seberapa tinggi tanggapan para pembaca, kritikus sastra, dan peneliti sastra. Adakah karya-karyanya mampu membeberkan sesuatu yang berbeda tentang kehidupan sehingga menarik untuk dijadikan objek studi sastra atau objek kajian dalam berbagai forum sastra.

Novel Kantring Genjer-Genjer dengan label Dari Kitab Kuning Sampai Komunis adalah novel karya Teguh Winarsho yang berkisah tentang dua pertentangan kaum abangan dan kaum santri. Kaum abangan adalah masyarakat yang menekankan aspek-aspek animisme atau kepercayaan terhadap adanya makhluk halus yang dapat mempengaruhi hidup manusia (Geertz, 1981:6). Sementara itu, kalangan santri diidentikkan dengan kelompok yang melaksanakan doktrindoktrin Islam yang lebih murni bukan saja pada tata cara pokok peribadatannya, namun juga dalam keseluruhan yang kompleks dari organisasi sosial (Geertz, 1981:7).

Masyarakat yang digambarkan dalam novel $K K G$ adalah masyarakat yang sangat dekat dengan Teguh Winarsho. Selain itu, Teguh Winarsho dalam $K G G$ juga mengusung nilai-nilai otentik sebagai pandangan dunia yang diperjuangkan kelompok sosial kaum santri yang Teguh Winarsho juga merupakan bagian di dalam kelompok sosial tersebut. 


\section{METODE}

Penelitian yang dilakukan ini merupakan penelitian kepustakaan. Data primer penelitian adalah novel $K G G$ karya Teguh Winarsho. Sementara itu, data sekunder adalah bahan-bahan kepustakaan yang memiliki relevansi dan bersifat menunjang penelitian. Penelitian ini menggunakan teori sastra sosiologi sastra strukturalisme genetik Lucien Goldmann. Sementara metode yang digunakan adalah metode dialektik. Metode ini merupakan metode yang khas dari teori strukturalisme genetik. Dari segi titik awal dan titik akhir, metode dialektik sama dengan metode positivistik. Keduanya sama-sama bermula dan berakhir pada teks sastra. Hanya saja, metode posistivistik tidak mempertimbangkan persoalan koherensi struktural, sedangkan metode dialektik justru memperhitungkannya (Goldmann, 1977: 8).

Metode dialektik mengukuhkan pandangan bahwa tidak ada titik awal yang mutlak, tidak ada persoalan yang secara mutlak dan pasti terpecahkan karena dalam sudut pandang tersebut pikiran tidak pernah bergerak seperti gerak lurus. Setiap fakta atau gagasan individual mempunyai arti hanya jika ditempatkan dalam keseluruhan. Sebaliknya, keseluruhan dapat dipahami dengan pengetahuan yang bertambah mengenai fakta-fakta parsial yang membangun keseluruhan itu. Karena keseluruhan tidak dapat dipahami tanpa bagian dan bagian tidak dapat dimengerti tanpa keseluruhan, proses pencapaian pengetahuan dengan metode dialektik menjadi semacam gerak yang melingkar terus-menerus, tanpa diketahui tempat atau titik yang menjadi pangkal ujungnya (Faruk, 2010: 77-78). Metode dialektik bekerja dengan pemahaman bolak-balik, antara struktur teks, pandangan dunia, dan struktur sosial.

\section{HASIL DAN PEMBAHASAN}

\section{Pandangan Dunia Humanisme Teosentris Dalam Struktur Sosial Pengarang}

Humanisme teosentris merupakan sebuah gagasan kemanusiaan yang berpedoman kepada ajaran-ajaran agama (Tuhan). Dalam terminologi humanisme teosentris, terdapat istilah teosentris yang membedakan gagasan ini dengan gagasan humanisme universal. Teosentris dalam etimologinya berasal dari bahasa Yunani, yakni Theo (Tuhan) dan centris (pusat), sehingga teosentris dapat dimaknai sebagai sebuah pandangan yang menilai bahwa Tuhan adalah pusat atau sumber tertinggi dari semua ajaran moral dan etika.

Konsep humanisme teosentris muncul sebagai upaya untuk menyatukan nilai-nilai agama dan kemanusiaan. Keyakinan tentang Tuhan (ajaran agama) mempengaruhi watak dan persepsi manusia yang selanjutnya menentukan kedudukan dirinya, prioritas kebutuhan dan pembentukan 
kaidah hubungan dengan manusia lainnya. Agama bukan hanya sistem kepercayaan yang tidak berubah tetapi juga nilai yang berorientasi kemanusiaan. Oleh karena setiap manusia terlahir dalam fitrah, maka semua agama memiliki misi menjaga nilai kefitrahan yang dimilikinya dan menuju kebahagiaan abadi. Dengan kata lain, humanisme teosentris adalah keyakinan dalam aksi, pengakuan bahwa Tuhan adalah pusat orientasi sejak awal kehidupan manusia. Orientasi ketuhanan tersebut harus hidup dalam jiwa dan kehidupan manusia, seperti dalam tradisi, adat-istiadat dan tata krama. Inilah yang membedakan konsep humanisme teosentris (humanisme berdasarkan agama) dengan humanisme sekuler (Mustofa, 2011:12).

Humanisme teosentris memandang bahwa segala sesuatu yang dilakukan oleh manusia dikembalikan kepada Tuhan, inilah esensi dari azas-azas tauhid yang diajarkan di dalam Islam. Dengan demikian, maka dapat dipahami bahwa gagasan humanisme teosentris berbeda dengan gagasan humanisme klasik. Walaupun kedua pandangan tersebut sama-sama meletakkan manusia sebagai unsur "teratas" dalam rantai kehidupan di dunia tetapi penambahan "teosentris" memberikan sifat lain di dalam kerangka humanisme, yaitu keyakinan yang lebih mendalam terhadap Tuhan dan manusia sebagai makhluk Tuhan (Achmadi, 2005:20).

Gagasan humanisme teosentris dalam Islam secara garis besar menempatkan sisi manusiawi sesuai kodratnya sebagai makhluk ciptaan Tuhan. Secara kodrati, ada tiga hal yang menjadi pokok pemikiran di dalam humanisme Islam (humanisme teosentris), yakni 1). Manusia sebagai hamba Tuhan, hal ini akan berkaitan dengan dengan tanggung jawab manusia di dunia sebagai khalifah (wakil Tuhan), peran dan fungsinya dalam menciptakan harmonisasi kehidupan di dunia. 2) Manusia sebagai makhluk yang berfikir dan berilmu; dan 3). Manusia sebagai makhluk yang beradab, yang menjunjung nilai-nilai moral (akhlak) (Achmadi, 2005:27).

Berdasarkan penjelasan tersebut di atas, pesantren sebagai lembaga pendidikan keagamaan (Raharjo, 1985: viii) dan memiliki hubungan erat dengan Teguh Winarsho sebagai pengarang novel $K G G$ tidak berlebihan jika dikatakan sebagai lembaga pendidikan yang juga mengedepankan pandangan dunia humanisme teosentris. Hal ini karena pesantren adalah lembaga pendidikan Islam yang mempelajari, memahami, mendalami, menghayati dan mengamalkan ajaran Islam dengan menekankan pentingnya moral keagamaan sebagai pedoman perilaku sehari-hari (Mastuhu, 1994: 32). Adapun tujuan pendidikan pesantren adalah menciptakan dan mengembangkan kepribadian muslim, yaitu kepribadian beriman dan bertaqwa kepada Tuhan, berakhlak mulia, bermanfaat bagi masyarakat atau berkhidmad kepada masyarakat dengan jadi kawulo atau abdi masyarakat, yaitu menjadi pelayan masyarakat sebagaimana kepribadian Nabi Muhammad SAW (mengikuti sunah 
Nabi), mampu berdiri sendiri, bebas dan teguh dalam kepribadian, menyebarkan agama atau menegakkan Islam serta kejayaan umat Islam di tengah-tengah masyarakat, dan mencintai ilmu dalam rangka mengembangkan kepribadian, pengembangan kepribadian yang ingin dituju ialah kepribadian muhsin (orang yang baik dan berakhlak mulia) bukan sekedar muslim (Khamdan, 2010: 19).

Dalam dunia pesantren, masalah pendidikan akhlak (moral) sangat penting sehingga dalam praktik pengajarannya menggunakan tiga pola sekaligus. Pertama, materi ini diajarkan secara hidden atau tersembunyi yang hampir dijumpai pada semua mata pelajaran pesantren yang ada. Kedua, materi ini diajarkan secara khusus melalui kitab-kitab yang tersedia. Ketiga, materi ini diaplikasikan dalam kehidupan praktis sehari-hari di pesantren. Kehidupan di pesantren dengan sistem asramanya mewujudkan secara nyata apa yang diajarkan atau diterima oleh santri. Adapun tujuan pembelajaran moral adalah membentuk santri agar memiliki kepribadian muslim yang bermoral, baik dalam hubungannya dengan Tuhan (hablum minallah) maupun dalam hubungannya dengan manusia (hablum minannas) serta dalam hubungannya dengan alam sekitar atau makhluk lainnya (Maksum, 2003:44).

Keberadaan pesantren beserta perangkatnya yang ada adalah sebagai lembaga pendidikan dan dakwah serta lembaga kemasyarakatan yang memberikan warna terhadap lingkungan sekitarnya. Ia tumbuh dan berkembang bersama warga masyarakatnya sejak berabad-abad. Oleh karena itu, tidak hanya secara kultural diterima, tetapi telah ikut serta membentuk dan memberikan corak serta nilai kehidupan kepada masyarakat yang senantiasa tumbuh dan berkembang. Figur kyai, santri serta seluruh perangkat fisik yang menandai sebuah pesantren senantiasa dikelilingi oleh sebuah kultur yang bersifat keagamaan. Kultur tersebut mengatur perilaku seseorang, pola hubungan antar warga masyarakat bahkan hubungan antara satu masyarakat, dengan masyarakat lainnya (Hasan dalam Oepen, dkk., 1988: 109).

Tujuan pendidikan pesantren tidak semata-mata untuk memperkaya pikiran para santri dengan penjelasan-penjelasan, tetapi untuk meningkatkan moral, melatih dan mempertinggi semangat, menghargai nilai-nilai spiritual dan kemanusiaan, mengajarkan tingkah laku yang jujur dan bermoral, (Dhofier, 1982: 18).

Pondok Pesantren Assalam Surakarta yang merupakan lembaga pendidikan keagamaan yang ikut serta membentuk pandangan dunia Teguh Winarsho, merupakan pesantren yang memiliki pandangan dunia yang kurang lebih sama dengan pandangan dunia humanisme teosentris. Pandangan dunia yang demikian dapat dilihat dari visi dan misi pondok pesantren Assalam 
Surakarta yang merupakan dasar utama pelaksanaan program pendidikannya. Visi utama pondok pesantren Assalam Solo adalah terwujudnya insan yang memiliki keseimbangan spiritual, intelektual, dan moral menuju generasi ulul albab (berkualitas/bermartabat) yang berkomitmen tinggi terhadap kemaslahatan umat dengan berlandaskan Alquran dan As-Sunnah. Sementara misi utama pondok pesantren Assalam Solo adalah menyelenggarakan proses pendidikan Islam yang berorientasi pada mutu, berdaya saing tinggi, dan berbasis pada sikap spiritual, inetelektual dan moral guna mewujudkan kader umat yang menjadi rahmatan lil alamin (QS. 9 :122); Mengembangkan pola kerja pondok pesantren dengan berbasis pada manajemen profesional yang Islami guna menciptakan suasana kehidupan di lingkungan pondok yang tertib, aman dan damai (QS. 56: 26, QS 9:105, QS 67:2); Meningkatkan citra positif lembaga pendidikan pondok pesantren yang berwawasan sains dan teknologi informasi serta berbudaya modern yang Islami (QS. 39:18). Sementara itu, tujuan akhir yang ingin dicapai pondok pesantren adalah tercapainya manusia yang berilmu dan bertaqwa kepada Allah SWT, berakhlak mulia dan mampu mengaktualisasikan diri dalam kehidupan bermasyarakat yang plural berdasarkan Alquran dan As-Sunnah (https://assalaam.or.id/sample-page-2/vision-and-mission/, diunduh 20 Maret 2020).

Berdasarkan penjelasan tentang humanisme teosentris, pesantren dan gambaran visi misi pesantren Assalam Surakarta tersebut di atas dapat disimpulkan bahwa Teguh Winarsho sebagai pengarang novel $K G G$ yang memiliki kedekatan dengan pesantren diasumsikan memiliki pandangan dunia humanisme teosentris. Pandangan dunia Teguh Winarsho tersebut juga dapat dilihat dari kokretisasi yang telah dilakukannya dalam novel $K G G$.

\section{Humanisme Teosentris dalam Struktur Novel $K G G$}

Setelah dilakukan pembacaan terhadap novel $K G G$ ditemukan pandangan dunia humanisme teosentris Teguh Winarsho terletak pada bagaimana menjadi manusia yang bermartabat yang sadar akan jati dirinya sebagai hamba Tuhan yang memiliki tugas sebagai khalifah (wakil tuhan) di muka bumi, manusia yang berilmu dan manusia yang berakhlak. Bersama-sama dengan kelompok sosial kaum santri, Teguh Winarsho memperjuangkan pandangan dunianya yaitu pandangan dunia humanisme teosentris, yang tercermin dalam salah satu karyanya, yaitu novel $K G G$.

Pandangan dunia humanisme teosentris Teguh Winarsho ini kemudian digambarkan melalui tokoh utama dalam relasinya dengan tokoh-tokoh lain serta relasinya dengan dunia sekitarnya. Tokoh utama dalam novel $K G G$, aku (Nyoto), digambarkan sebagai seorang pemuda yang mengalami problematika atas masyarakatnya. Tokoh aku digambarkan menjalin relasi dengan 
tokoh-tokoh lain dalam novel $K G G$. Tokoh-tokoh lain yang dimaksud adalah Kantring, Ki Sangir, dan Lasmi. Relasi tokoh $a k u$ dengan tokoh-tokoh lain ini dihadirkan dengan tujuan untuk menggambarkan pandangan dunia humanisme teosentris pengarang. Demikian halnya relasi tokoh $a k u$ dengan dunianya yaitu dusun Panjen, pesantren dan kali Krasak. Relasi ini juga merupakan representasi dari pandangan dunia humanisme teosentris Teguh Winarsho.

Gagasan Humanisme teosentris Teguh Winarsho tumbuh sebagai reaksi atas budaya masyakat muslim yang dianggap menyimpang dari ajaran agama dan kepercayaannya. Perwujudan gagasan humanisme teosentris yang terdapat dalam novel $K G G$ yaitu melalui hubungan baik antar sesama manusia dengan didasari keyakinan akan Tuhannya. Dengan demikian dapat tercipta kehidupan yang lebih baik antar sesama dan masing-masing individu mendapatkan kebebasan untuk merealisasikan dirinya menjadi manusia yang bermartabat. Hubungan sesama manusia dalam novel $K G G$ yang mewakili pandangan dunia humanisme teosentris adalah hubungan atau relasi antara hero (Nyoto) dengan Kantring dan Lasmi.

Dalam relasinya dengan Kantring, hero sadar bahwa seorang muslim harus selalu menyadari akan keberadaan Tuhannya, berpegang teguh pada sumber ajaran Islam dan berlaku baik kepada sesama manusia. Pada saat para kuli pengangkut batu mengikuti ajaran Ki Sangir (ayah tokoh hero), hero problematik tetap bertahan di pesantren Kiai Barnawi sebagaimana diharapkan Kantring ibunya. Hero sendiri juga yakin bahwa ajaran yang ada di Pesantren Kiai Barnawi adalah ajaran yang benar dan sesuai dengan kodrat manusia yang bermartabat.

Kantring menginginkan anaknya menjadi manusia yang baik dan sadar akan jati dirinya sebagai makhluk Tuhan. Hal ini dalam $K G G$ ditunjukkan melalui sebuah surat yang ditulis Kantring sebelum kematiannya. Kantring merasa senang karena $a k u$ giat belajar ajaran agama kepada Kiai Barnawi dari pada mengikuti ajaran sesat ayahnya. Kantring yakin bahwa ajaran Islam yang didapatkan dari Kiai Barnawi akan memberikan manfaat bagi dirinya dan orang lain, sedangkan ajaran sesat Ki Sangir akan membawa bencana bagi penduduk sekitar dan orang-orang terdekatnya termasuk istrinya sendiri. Selain itu, Kantring juga menginginkan anaknya menjadi orang yang baik dan berguna bagi negara dan agama. Hal ini dalam $K G G$, ditampilkan pengarang melalui dua kutipan novel berikut ini.

(1).“Akoe coekoeplah senang kamoe banjak menghabiskan waktoe loeang oentoek kamoe perboeat mengadji di pesantren Kiai Barnawi daripada haroes menerima adjaran-adjaran Ki Sangir, ajahmoe sendiri. Semoea adjaran ajahmu mebawa bentjana boeat pendoedoek Panjen dan joega boeatkoe sendiri ( $K G G: 49)$. 
(2) Djadilah kamoe anak jang berguna bagi negara dan agama. Berboeatlah kebenaran di mana sadja kamoe berada meski banjak orang jang menghina-hina ( $K G G: 53)$.

Dari kedua kutipan novel tersebut menunjukkan nilai-nilai otentik yang sedang dicari oleh hero problematik dan cara pencarian yang dilakukan sang hero. Nilai-nilai otentik yang dimaksud adalah nilai-nilai otentik yang bersumber dari ajaran agama yang benar dan memberikan manfaat bagi kemanusiaan, negara dan agama. Sementara, cara yang ditawarkan untuk dapat menemukan nilai-nilai otentik tersebut adalah melalui proses pendidikan, baik pendidikan agama maupun pendidikan umum. Hal ini juga diperkuat dengan keteguhan dan semangat yang tinggi serta tidak menghiraukan orang-orang yang menentang atau menghalang-halangi dalam proses pencarian nilainilai otentik tersebut.

Dari penjelasan tersebut di atas, dapat disimpulkan bahwa humanisme teosentris merupakan pandangan dunia yang ada dalam novel $K G G$. Pandangan dunia humanisme teosentris merupakan refleksi sosiobudaya yang mempengaruhi latar belakang kehidupan Teguh Winarsho sebagai pengarang. $K G G$ dapat dipandang sebagai ekspresi kesadaran Teguh Winarsho terhadap masyarakatnya. Teguh Winarsho mentransformasikan kondisi masyarakatnya tersebut ke dalam tokoh-tokoh dan objek-objek yang diciptakan dalam novelnya. Humanisme teosentris dipandang sebagai sebuah pandangan dunia yang menghubungkan struktur teks novel dengan struktur sosial pengarang.

\section{SIMPULAN}

Berdasarkan pembahasan novel $K G G$ dengan teori strukturalisme genetik dengan metode dialektik dapat disimpulkan sebagai berikut.

Pertama, struktur teks novel $K G G$ berpusat pada relasi antara tokoh dengan tokoh dan tokoh dengan objek-objek yang ada sekitarnya. Tokoh-tokoh, objek-objek, serta relasi-relasi yang ada dalam novel $K G G$ pada umumnya bercerita tentang manusia yang hidup dalam masyarakat yang kondisinya serba sulit dan penuh problema. Untuk menghadapi kehidupan yang demikian itu, manusia memerlukan suatu pegangan untuk tetap bertahan hidup menjadi manusia yang bermartabat, mampu menjaga hubungan baik dengan sesama manusia dan hubungan baik dengan Tuhannya. Pegangan yang dimaksud adalah seperangkat nilai yang terkandung dalam agama, dalam hal ini agama Islam. Islam adalah agama yang tidak hanya mengajarkan hubungan baik dengan Tuhan semata, tetapi juga memiliki keterkaitan dengan hubungan baik antar sesama manusia. 
Kedua, pandangan dunia pengarang yang dapat diformulasikan berdasarkan analisis struktur teks novel $K G G$ adalah humanisme teosentris. Pandangan dunia humanisme teosentris yang dimaksud merupakan bentuk perwujudan tentang kesadaran dan ikhtiar manusia untuk menghidupkan rasa perikemanusiaan, serta mencita-citakan pergaulan hidup yang lebih baik antarsesama manusia. Nilai-nilai tersebut muncul dari dalam diri manusia secara personal, diwujudkan dalam pikiran, perkataan, maupun perbuatannya yang utama. Tujuan akhirnya adalah terbentuknya identitas manusia sebagai makhluk yang baik dan penuh cinta antarsesama manusia (hablumminannas), dan berbakti kepada Tuhan semesta alam (hablumminallah). Pandangan dunia humanisme teosentris yang ada dalam novel $K G G$ merupakan hasil ekspresi seorang anggota kelompok sosial pengarang, yakni kelompok sosial kaum santri yang memiliki misi kemanusiaan dengan mendasarkan diri pada ajaran-ajaran kebaikan yang bersumber dari Tuhan (ajaran agama Islam).

Ketiga, dari kajian sosial budaya masyarakat yang ada di sekitar penciptaan novel $K G G$, diketahui bahwa novel $K G G$ bukan hanya merupakan karya imajinatif pengarang semata, melainkan novel yang mempunyai kaitan erat dengan masyarakatnya. Novel $K G G$ merupakan suatu bentuk karya sastra genre novel yang mencoba memberikan respon terhadap kondisi sosial dan budaya masyarakatnya.

Secara keseluruhan antara struktur teks novel, pandangan dunia yang diekspresikan dan kondisi sosial masyarakat pengarang terdapat hubungan yang erat satu dengan yang lainnya. Intinya, karya ini tidak dapat dilepaskan dari lingkungan sosialnya, serta tidak hanya menjadi refleksi pasif, reproduksi semata-mata realitas, tetapi merupakan hasil strukturasi terhadap realitas sosial dan kultural. Dengan demikian, novel $K G G$ juga berharga secara struktural.

\section{DAFTAR RUJUKAN}

Achmadi. 2005. Ideologi Pendidikan Islam: Paradigma Humanisme Teosentris. Yogyakarta: Pustaka Pelajar

Damono, Sapardi Djoko. 1978. Sosiologi Sastra: Sebuah Pengantar Ringkas. Jakarta: Pusat Pengembangan Bahasa, Departemen Pendidikan dan Kebudayaan

Faruk. 2010. Pengantar Sosiologi Sastra, dari Strukturalisme Genetik sampai Posmodern. Yogyakarta: Pustaka Pelajar

Geertz, Clifford. 1981. Abangan, Santri, Priyayi: dalam Masyarakat Jawa. Terjemahan Aswab Mahasin. Jakarta: Pustaka Jaya

Goldmann, Lucien. 1970. "The Sociology of Literature: Status And Problems of Method" Dalam The Sociology of Literature (Milton C. Arlbrecht Cs. Eds.) New York: Praeger Publisher. 
1977. The Hidden God, a Study of Tragic Vision in the Pensees of Pascal and the Tragedies of Racine. Translated Into English by Philip Thody. London and Henley: Routledge \& Kegan Paul

Khamdan, Muhammad. 2010. Pesantren di Dalam Penjara: Sebuah Model Pembangunan Karakter. Kudus: Penerbit Parist

Maksum. 2003. Pola Pembelajaran di Pesantren. Jakarta: Ditpekapontren Ditjen Kelembagaan Agama Islam Departemen Agama

Mastuhu. 1994. Dinamika Sistem Pendidikan Pesantren. Jakarta: INIS

Mustofa. 2011. "Nilai-Nilai Humanisme Islam dan Implikasinya Dalam Tujuan Pendidikan”. dalam Jurnal Didaktika Islamika, Vol. XI. No. 2 Desember 2011

Oepen, Manfred dan Wolfgang Karcher. 1988. Dinamika Pesantren. Terj. Sonhaji Saleh. Jakarta: P3M

Raharjo, Dawam. 1985. Pesantren dan Pembaharuan. Jakarta: LP3ES

Sumardjo, Jacob. 1982. Masyarakat dan Sastra Indonesia. Yogyakarta: Nur Cahaya.

----------. 1991. Pengantar Novel Indonesia. Jakarta: Karya Unipress

Winarsho, Teguh. 2006. Kantring Genjer-Genjer, dari Kitab Kuning sampai Komunis. Lamongan: Pustaka Pujangga

Zamakhsyari Dhofier. 1982. Tradisi Pesantren Studi tentang Pandangan Hidup Kiai. Jakarta: LP3ES

PP. Assalam. 2020. "Vission and Mission PP. Assalam" (https://assalaam.or.id/sample-page2/vision-and-mission/), diunduh 20 Maret 2020 